\title{
3 Research Square

\section{Molecular Characterization and Overexpression of CYP51 gene of Difenoconazole Resistance in Lasiodiplodia Theobromae Field Isolates}

Chenguang Wang

Hainan University

Luxi Xu

Hainan University

Xiaoyu Liang

Hainan University

Jing Wang

Hainan University

Xinwei Xian

Hainan University

Yu Zhang

Hainan University

Ye Yang ( $\nabla$ yyyzi@tom.com )

Hainan University

\section{Research Article}

Keywords: Lasiodiplodia theobromae, Mango, difenoconazole, fungicide resistance, CYP51 gene, gene expression

Posted Date: July 7th, 2021

DOI: https://doi.org/10.21203/rs.3.rs-658804/v1

License: (c) (1) This work is licensed under a Creative Commons Attribution 4.0 International License. Read Full License

Version of Record: A version of this preprint was published at Scientific Reports on December 1st, 2021. See the published version at https://doi.org/10.1038/s41598-021-03601-4. 


\section{Abstract}

Stem-end rot (SER) caused by Lasiodiplodia theobromae is an important disease of mango in China. Demethylation inhibitor (DMI) fungicide are widely used for diseases control in mango orchards. The baseline sensitivity to difenoconazole of 138 isolates collected in the field in 2019 from mango were established by the mycelial growth rate method. The cross-resistance to six site-specific fungicides with different modes of action were investigated using 20 isolates randomly selected. The possible reasons for $L$. theobromae resistance to difenoconazole were preliminarily determined through gene sequence alignment and quantitative real-time PCR analysis. The results showed that the $\mathrm{EC}_{50}$ values of $138 \mathrm{~L}$. theobromae isolates to difenoconazole ranged from 0.01 to $13.72 \mu \mathrm{g} / \mathrm{ml}$. The frequency of difenoconazole sensitivity formed a normal distribution curve when the outliers were excluded. Difenoconazole showed positive cross-resistance only with the DMI tebuconazole, but not with non-DMI carbendazim, pyraclostrobin, fludioxonil, bromothalonil, or iprodione. Some multifungicide-resistant isolates of L. theobromae were found. Two amino acid substitutions (E209k and G207A) were found in CYP51 protein, but they were not likely related to the resistance phenotype. There was no alteration in promoter region of the CYP51 gene. However, difenoconazole significantly increased the expression of the CYP51 gene in the resistant isolates when compared to the susceptible isolates. This study is important references to explore resistance mechanism. These results are vital to make effective mango diseases management strategies in order to avoid the development of further resistance.

\section{Introduction}

Mangoes (Mangifera indica L.) known as the 'king of tropical fruits' is one of the main tropical and subtropical fruits, widely appreciated for their economic value and their high nutritional value ${ }^{1}$. China is the world's second-largest mango grower, being only inferior to India. The main mango-producing area in China is Hainan province, which the mango planting area has exceeded 56,900 hectares in $2019^{2}$. The majority of mangoes are intended for fresh-market consumption. Thus, any surface flaws will impact fruit sales. In Hainan, Lasiodiplodia theobromae is the main pathogen causing stem-end rot (SER) of mango ${ }^{3}$. This fungus may establish itself in the field asymptomatically and stay in a quiescent state. The pathogen express after the fruit has been harvested, which will cause fruit rot and serious damage to the quality of fruit in storage and transportation of mango, and cause huge economic losses ${ }^{4-6}$. It can also infect various plants and cause diseases in the field and storage period, including the blueberry ${ }^{7}$, coconut $^{8}$, papaya ${ }^{9}$, longan fruit ${ }^{10}$, and so on. Since no cultivars show resistance to $L$. theobromae, the control of SER disease has depended on chemical control. Fungicide benzimidazole methylcarbamate (MBCs) and sterol $14 \alpha$-demethylase inhibitors (DMIs) are extensively used to control mango disease 11,12 .

The frequent use of chemical fungicides in fields increases fungicide-resistance of the pathogenic fungi. In Hainan Province of China, many DMls fungicides were frequently used to control various diseases during mango cultivation, which caused great pressure on the selection of fungicides for $L$. theobromae, 
and made the pathogen face the risk of serious resistance to fungicides. In order to determine the difenoconazole-resistance of $L$. theobromae in Hainan and to explore the mechanisms of resistance, the aim of this study were to (I) determine the sensitivity of L. theobromae isolates to difenoconazole; (II) identify the patterns of cross-resistance between difenoconazole and other DMls or fungicides that have different mechanisms of action than difenoconazole; (III) investigate the molecular mechanisms that may be responsible for difenoconazole resistance.

\section{Materials And Methods}

\section{Isolates and culture conditions.}

In 2019, 138 single-spore field isolates of $L$. theobromae were obtained from diseased mango fruits in Hainan Province, China, previously identified and preserved in our laboratory. At $28^{\circ} \mathrm{C}$ in the dark, the isolates were grown on a potato dextrose agar (PDA) medium.

\section{Determination of the baseline sensitivity of field isolates to difenoconazole.}

A mycelial growth inhibition assay was used to investigate the baseline sensitivity to difenoconazole of $138 \mathrm{~L}$. theobromae isolates ${ }^{13}$. To prepare stock solutions, difenoconazole (97.2\%; Zhengye Chemical Industrial Co., Hainan, China) was dissolved in $100 \%$ acetone to obtain $5 \times 10^{3} \mu \mathrm{g} / \mathrm{ml}$ solutions. A mycelial plug (5 mm in diameter) from the edge of the 3-day-old culture of each isolate was inoculated in $90 \mathrm{~mm}$ diameter Petri plates containing difenoconazole PDA media. The final concentration of acetone solvent in the medium was $0.1 \%$. The difenoconazole concentrations of $51.2,12.8,3.2,0.8,0.2 \mu \mathrm{g} / \mathrm{ml}$, as well as a control medium with the same amount of acetone but no fungicide. Inoculated plates were cultured in the dark at $28^{\circ} \mathrm{C}$. The diameter of each colony was measured, and the inhibition rate of mycelial development calculated after cultured for $36 \mathrm{~h}$. There were three replicate plates per treatment. The entire experiment was repeated twice independently. The frequency distribution of $138 \mathrm{EC}_{50}$ values of $L$. theobromae was plotted to represent the baseline sensitivity. The baseline sensitivity level of $L$. theobromae was used to develop classification criteria for difenoconazole sensitive phenotypes ${ }^{14,13}$. The resistance factor (RF) of each isolate to fungicide was computed using the baseline sensitivity: Sensitive isolates (S): $R F<5$; Resistant isolates (R): RF $>5^{15}$.

\section{Cross-resistance of difenoconazole with other fungicides.}

The cross-resistance of difenoconazole with other regularly used fungicides was investigated using 20 isolates. These comprised DMls fungicides tebuconazole and five fungicides of other action modes, which were carbendazim (benzimidazole), iprodione (dicarboximides), bromothalonil (bromomethyl glutaronitrile), fludioxonil (phenylpyrrole) and pyraclostrobin (strobilurin). As previously stated, $\mathrm{EC}_{50}$ 
values were calculated using a mycelial growth inhibition experiment. The $\mathrm{EC}_{50}$ values of the fungicides tested were used to determine cross-resistance correlations. The experiment was conducted three times independently, using three replicate plates for each treatment.

\section{Cloning and Sequencing of LtCYP51 Gene.}

Mycelia of $L$. theobromae were snap-frozen in liquid nitrogen and processed with tungsten beads in a LUKYM-II Mixer-Mill to extract total genomic DNA from 138 isolates (Guangzhou Luka sequencing instrument Co., LTD, Guangzhou, China). Total genomic DNA was extracted according to the manufacturer's instructions using the E.Z.N.A.® HP Plant DNA Mini kit (Omega Bio-Tek, Norcross, United States). Primer pairs, LtCYP51-F1/LtCYP51-R1, Per-1F/Per-1F (Table 1), were designed to amplify the LtCYP51 coding sequence and LtCYP51 promoter of resistant and sensitive isolates. Amplications were performed in a My Cycler thermal cycler (Bio-Rad Laboratories, Hercules, CA, USA). A $40 \mu \mathrm{L}$ reaction volume was used for PCR amplification, with $20 \mu \mathrm{L}$ of $2 \times$ Phanta Max Master Mix, $0.8 \mu \mathrm{L}$ of template DNA, $1.6 \mu \mathrm{L}$ of $(10 \mathrm{mM})$ each primer, and $16 \mu \mathrm{L}$ of ddH2O. The PCR settings for the coding sequence were $95^{\circ} \mathrm{C}$ for $3 \mathrm{~min}$, followed by 35 cycles of $95^{\circ} \mathrm{C}$ for $30 \mathrm{~s}, 58^{\circ} \mathrm{C}$ for $50 \mathrm{~s}$, and $72^{\circ} \mathrm{C}$ for $90 \mathrm{~s}$, followed by a final 5 -min extension at $72^{\circ} \mathrm{C}$.

Table 1

Primers utilized in this study.

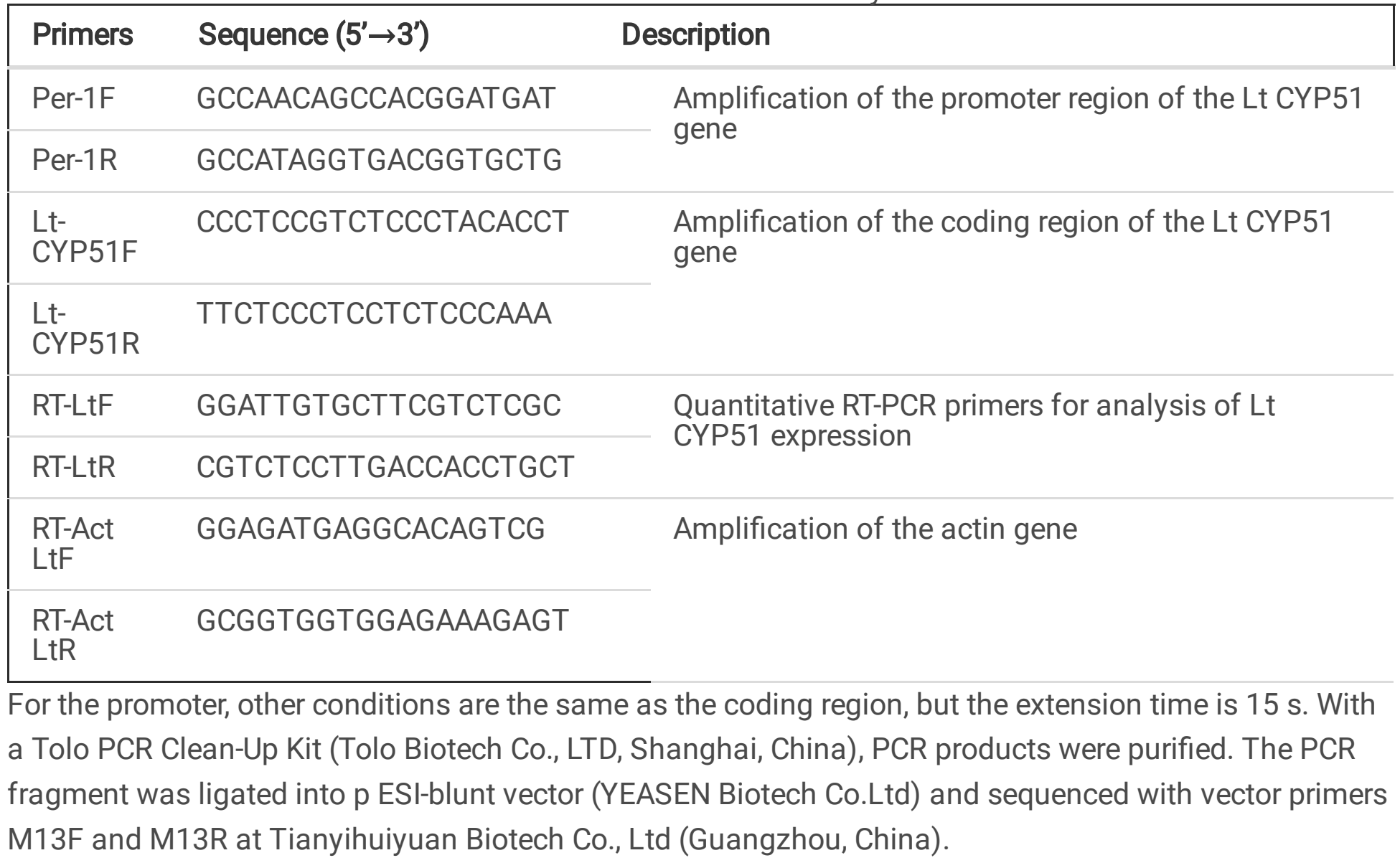


The LtCYP51 DNA sequence was studied using the programs DNAMAN (version 6.0; LynnonBiosoft, U.S.A.) and InterPro Scan (http://www.ebi.ac.uk/interpro/search/sequence-search), and it was compared to fungal of other LtCYP51 genes. The amino acid sequences of the LtCYP51 genes from difenoconazole-resistant and sensitive isolates were compared using the computer program EMBOSS Transeq (https://www.ebi.ac.uk/emboss/transeq/), which translated the DNA sequences into amino acid sequences using standard code.

Quantitative expression of LtCYP51 Gene. Among the 30 isolates used for amino acid mutation analysis, two sensitive isolates (YC70 and JS10) and six resistant isolates (LD10, SY31, YZ90, DZ11, SY05 and YC80) were randomly selected to study the expression of $L t C Y P 51$ gene. The $\mathrm{EC}_{50}$ values of 8 isolates (Table 2). Five mycelial plugs were transferred into a flask containing $100 \mathrm{ml}$ of potato dextrose broth (PDB) and incubated at $28^{\circ} \mathrm{C}$ for $24 \mathrm{~h}$ on a rotary shaker at $150 \mathrm{rpm}$. Three flasks were treated with difenoconazole to reach a final concentration of $150 \mu \mathrm{g} / \mathrm{ml}$, with three replicates. Three flasks containing $100 \mathrm{ml}$ of PDB were used as untreated controls. After being treated with difenoconazole for $12 \mathrm{~h}$, the mycelia of each isolate were removed for RNA extraction ${ }^{16}$. Total RNA was extracted using the TIANGEN RNA simple Total RNA kit (Tiangen Biotech Co., Ltd, Beijing, China), and cDNA was synthesized using the HiScript III 1st Strand cDNA Synthesis Kit with g DNA Eraser (Vazyme Biotech Co., Ltd, Nanjing, China), following the manufacturer's instructions. Every reaction has three biological replicates and three technological replicates. 
Table 2

The $\mathrm{EC}_{50}$ values of Lasiodiplodia theobromae isolates to seven fungicides

\begin{tabular}{|c|c|c|c|c|c|c|c|}
\hline \multirow[t]{2}{*}{ Isolates } & \multicolumn{7}{|c|}{$\mathrm{EC}_{50} \pm \mathrm{SD}(\mu \mathrm{g} / \mathrm{ml})^{\mathrm{a}}$} \\
\hline & Dif $^{b}$ & Car & Pyr & Flu & Bro & Ipr & Teb \\
\hline YC80 & $\begin{array}{l}7.59 \pm \\
0.23\end{array}$ & $\begin{array}{l}8016.29 \pm \\
658.34\end{array}$ & $\begin{array}{l}1913.83 \pm \\
158.46\end{array}$ & $\begin{array}{l}0.04 \pm \\
0.01\end{array}$ & $\begin{array}{l}11.68 \pm \\
1.92\end{array}$ & $\begin{array}{l}0.30 \pm \\
0.06\end{array}$ & $\begin{array}{l}0.97 \pm \\
0.11\end{array}$ \\
\hline SY06 & $\begin{array}{l}9.63 \pm \\
0.66\end{array}$ & $3.37 \pm 0.28$ & $1.75 \pm 0.25$ & $\begin{array}{l}0.08 \pm \\
0.01\end{array}$ & $\begin{array}{l}9.52 \pm \\
1.27\end{array}$ & $\begin{array}{l}0.53 \pm \\
0.09\end{array}$ & $\begin{array}{l}1.87 \pm \\
0.13\end{array}$ \\
\hline LD13 & $\begin{array}{l}1.99 \pm \\
0.22\end{array}$ & $0.02 \pm 0.01$ & $\begin{array}{l}344.93 \pm \\
45.72\end{array}$ & $\begin{array}{l}0.17 \pm \\
0.02\end{array}$ & $\begin{array}{l}14.89 \pm \\
1.63\end{array}$ & $\begin{array}{l}0.36 \pm \\
0.05\end{array}$ & $\begin{array}{l}0.33 \pm \\
0.08\end{array}$ \\
\hline SY34 & $\begin{array}{l}10.14 \pm \\
0.91\end{array}$ & $\begin{array}{l}1792.64 \pm \\
176.28\end{array}$ & $\begin{array}{l}213.41 \pm \\
19.33\end{array}$ & $\begin{array}{l}0.04 \pm \\
0.01\end{array}$ & $\begin{array}{l}10.02 \pm \\
1.15\end{array}$ & $\begin{array}{l}0.23 \pm \\
0.06\end{array}$ & $\begin{array}{l}1.11 \pm \\
0.09\end{array}$ \\
\hline YC70 & $\begin{array}{l}0.97 \pm \\
0.52\end{array}$ & $0.09 \pm 0.01$ & $79 \pm 5.38$ & $\begin{array}{l}0.03 \pm \\
0.01\end{array}$ & $\begin{array}{l}2.08 \pm \\
0.46\end{array}$ & $\begin{array}{l}0.23 \pm \\
0.07\end{array}$ & $\begin{array}{l}0.07 \pm \\
0.01\end{array}$ \\
\hline SY05 & $\begin{array}{l}6.52 \pm \\
0.40\end{array}$ & $0.38 \pm 0.02$ & $\begin{array}{l}260.01 \pm \\
19.62\end{array}$ & $\begin{array}{l}0.05 \pm \\
0.01\end{array}$ & $\begin{array}{l}7.83 \pm \\
0.98\end{array}$ & $\begin{array}{l}0.37 \pm \\
0.08\end{array}$ & $\begin{array}{l}0.68 \pm \\
0.07\end{array}$ \\
\hline SY31 & $\begin{array}{l}6.24 \pm \\
0.33\end{array}$ & $1.08 \pm 0.14$ & $83.21 \pm 8.45$ & $\begin{array}{l}0.26 \pm \\
0.03\end{array}$ & $\begin{array}{l}5.04 \pm \\
0.56\end{array}$ & $\begin{array}{l}0.25 \pm \\
0.09\end{array}$ & $\begin{array}{l}0.60 \pm \\
0.08\end{array}$ \\
\hline DZ11 & $\begin{array}{l}8.29 \pm \\
0.36\end{array}$ & $2.68 \pm 0.38$ & $\begin{array}{l}429.48 \pm \\
47.83\end{array}$ & $\begin{array}{l}0.04 \pm \\
0.01\end{array}$ & $\begin{array}{l}5.33 \pm \\
0.40\end{array}$ & $\begin{array}{l}0.40 \pm \\
0.06\end{array}$ & $\begin{array}{l}0.84 \pm \\
0.09\end{array}$ \\
\hline AM82 & $\begin{array}{l}1.03 \pm \\
0.85\end{array}$ & $\begin{array}{l}5447.84 \pm \\
529.11\end{array}$ & $\begin{array}{l}210.77 \pm \\
20.45\end{array}$ & $\begin{array}{l}0.11 \pm \\
0.02\end{array}$ & $\begin{array}{l}7.33 \pm \\
0.72\end{array}$ & $\begin{array}{l}0.54 \pm \\
0.08\end{array}$ & $\begin{array}{l}0.17 \pm \\
0.02\end{array}$ \\
\hline YZ31 & $\begin{array}{l}7.22 \pm \\
0.63\end{array}$ & $8.39 \pm 0.96$ & $\begin{array}{l}133.87 \pm \\
11.23\end{array}$ & $\begin{array}{l}0.06 \pm \\
0.01\end{array}$ & $\begin{array}{l}6.46 \pm \\
0.75\end{array}$ & $\begin{array}{l}0.42 \pm \\
0.03\end{array}$ & $\begin{array}{l}0.81 \pm \\
0.09\end{array}$ \\
\hline CJ20 & $\begin{array}{l}2.61 \pm \\
0.57\end{array}$ & $\begin{array}{l}0.0001 \pm \\
0.00\end{array}$ & $25.9 \pm 1.99$ & $\begin{array}{l}0.11 \pm \\
0.02\end{array}$ & $\begin{array}{l}8.90 \pm \\
0.66\end{array}$ & $\begin{array}{l}0.23 \pm \\
0.05\end{array}$ & $\begin{array}{l}0.47 \pm \\
0.06\end{array}$ \\
\hline YZ01 & $\begin{array}{l}5.39 \pm \\
0.92\end{array}$ & $1.17 \pm 0.16$ & $8.09 \pm 0.93$ & $\begin{array}{l}0.09 \pm \\
0.01\end{array}$ & $\begin{array}{l}7.36 \pm \\
0.97\end{array}$ & $\begin{array}{l}0.32 \pm \\
0.04\end{array}$ & $\begin{array}{l}0.42 \pm \\
0.05\end{array}$ \\
\hline CJ01 & $\begin{array}{l}0.73 \pm \\
0.33\end{array}$ & $0.52 \pm 0.04$ & $54.02 \pm 6.35$ & $\begin{array}{l}0.15 \pm \\
0.02\end{array}$ & $\begin{array}{l}10.54 \pm \\
0.94\end{array}$ & $\begin{array}{l}0.30 \pm \\
0.04\end{array}$ & $\begin{array}{l}0.40 \pm \\
0.07\end{array}$ \\
\hline AM24 & $\begin{array}{l}2.22 \pm \\
0.30\end{array}$ & $1.15 \pm 0.12$ & $9.98 \pm 1.21$ & $\begin{array}{l}0.10 \pm \\
0.01\end{array}$ & $\begin{array}{l}8.90 \pm \\
0.81\end{array}$ & $\begin{array}{l}0.25 \pm \\
0.16\end{array}$ & $\begin{array}{l}0.40 \pm \\
0.06\end{array}$ \\
\hline SY26 & $\begin{array}{l}8.53 \pm \\
1.17\end{array}$ & $1.05 \pm 0.10$ & $6.07 \pm 0.78$ & $\begin{array}{l}0.21 \pm \\
0.03\end{array}$ & $\begin{array}{l}6.07 \pm \\
0.83\end{array}$ & $\begin{array}{l}0.35 \pm \\
0.19\end{array}$ & $\begin{array}{l}0.98 \pm \\
0.08\end{array}$ \\
\hline
\end{tabular}

a Values in a column indicate $\mathrm{EC}_{50}$ means \pm standard deviation (SD). ${ }^{\mathrm{b}}$ Dif $=$ difenoconazole, Car $=$ carbendazim, $\mathrm{Pyr}=$ pyraclostrobin, $\mathrm{Flu}=$ fludioxonil, $\mathrm{Bro}=$ bromothalonil, $\mathrm{Ipr}=$ iprodione, $\mathrm{Teb}=$ tebuconazole. 


\begin{tabular}{|c|c|c|c|c|c|c|c|}
\hline \multirow[t]{2}{*}{ Isolates } & \multicolumn{7}{|c|}{$\mathrm{EC}_{50} \pm \mathrm{SD}(\mu \mathrm{g} / \mathrm{ml})^{\mathrm{a}}$} \\
\hline & Difb & Car & Pyr & Flu & Bro & Ipr & Teb \\
\hline LD34 & $\begin{array}{l}0.33 \pm \\
0.29\end{array}$ & $0.68 \pm 0.05$ & $16.58 \pm 1.75$ & $\begin{array}{l}0.08 \pm \\
0.01\end{array}$ & $\begin{array}{l}16.58 \pm \\
1.74\end{array}$ & $\begin{array}{l}0.42 \pm \\
0.05\end{array}$ & $\begin{array}{l}0.89 \pm \\
0.09\end{array}$ \\
\hline LD10 & $\begin{array}{l}6.64 \pm \\
0.41\end{array}$ & $\begin{array}{l}8537.14 \pm \\
721.73\end{array}$ & $\begin{array}{l}230.67 \pm \\
20.65\end{array}$ & $\begin{array}{l}0.12 \pm \\
0.02\end{array}$ & $\begin{array}{l}9.16 \pm \\
0.95\end{array}$ & $\begin{array}{l}0.25 \pm \\
0.07\end{array}$ & $\begin{array}{l}0.63 \pm \\
0.09\end{array}$ \\
\hline SY02 & $\begin{array}{l}11.56 \pm \\
0.72\end{array}$ & $2.63 \pm 0.45$ & $58.36 \pm 4.92$ & $\begin{array}{l}0.17 \pm \\
0.05\end{array}$ & $\begin{array}{l}8.05 \pm \\
0.75\end{array}$ & $\begin{array}{l}0.31 \pm \\
0.09\end{array}$ & $\begin{array}{l}1.59 \pm \\
0.03\end{array}$ \\
\hline JS10 & $\begin{array}{l}0.65 \pm \\
0.22\end{array}$ & $1.32 \pm 0.23$ & $\begin{array}{l}211.39 \pm \\
19.43\end{array}$ & $\begin{array}{l}0.05 \pm \\
0.01\end{array}$ & $\begin{array}{l}8.45 \pm \\
0.92\end{array}$ & $\begin{array}{l}0.31 \pm \\
0.08\end{array}$ & $\begin{array}{l}0.07 \pm \\
0.01\end{array}$ \\
\hline YZ90 & $\begin{array}{l}9.34 \pm \\
0.20\end{array}$ & $5.59 \pm 0.46$ & $\begin{array}{l}0.0008 \pm \\
0.00\end{array}$ & $\begin{array}{l}0.03 \pm \\
0.01\end{array}$ & $\begin{array}{l}5.59 \pm \\
0.63\end{array}$ & $\begin{array}{l}0.36 \pm \\
0.09\end{array}$ & $\begin{array}{l}0.98 \pm \\
0.09\end{array}$ \\
\hline \multicolumn{8}{|c|}{$\begin{array}{l}\text { aValues in a column indicate } \mathrm{EC}_{50} \text { means } \pm \text { standard deviation }(\mathrm{SD}) .{ }^{\mathrm{b}} \mathrm{Dif}=\text { difenoconazole, } \mathrm{Car}= \\
\text { carbendazim, } \mathrm{Pyr}=\text { pyraclostrobin, Flu = fludioxonil, Bro = bromothalonil, } \mathrm{Ipr}=\text { iprodione, } \mathrm{Teb}= \\
\text { tebuconazole. }\end{array}$} \\
\hline
\end{tabular}

Real-time PCR was carried out in a total volume of $20 \mu \mathrm{L}$ using the qTOWER3 G REAL-TIME PCR thermocycler (Analytik Jena AG, Jena, Germany). To amplify the genes, the $2 \times$ ChamQ Universal SYBR qPCR Master Mix (Vazyme Biotech Co., Ltd, Nanjing, China) was employed. The actin gene was amplified as a reference using the primer pair RT-Act LtF/RT-Act LtR to standardize the quantification of LtCYP51 expression ${ }^{17}$. Three repeats of the experiments were carried out.

\section{Statistical analysis.}

The inhibition rates were converted to the probability values, and difenoconazole concentrations were log 10-transformed before using a line regression model. The effective concentration to inhibit mycelial growth by $50 \%\left(\mathrm{EC}_{50}\right)$ was calculated by the regression equation. The $\mathrm{EC}_{50}$ values were checked for homogeneity of variances using Levene's test, then the $\mathrm{EC}_{50}$ values were calculated for each isolate by combining the data from both replications. The Shapiro-Wilk test was used to determine the normality of the frequency distribution of difenoconazole sensitivity, and the outliers were detected using the boxplot in SPSS 21.0. (IBM SPSS Statistics Version 21.0; IBM Corp., Armonk, NY, USA). The histograms were built utilising log 10-transformed $\mathrm{EC}_{50}$ values when the outliers were removed ${ }^{14,13}$. Spearman's rank correlation coefficient using log-transformed $\mathrm{EC}_{50}$ values was used to examine cross-resistance among seven fungicides ${ }^{18,19}$.To assess the differences in the relative expressions of gene, a one-way ANOVA with LSD test $(p<0.01)$. The difference of mean expression level was compared by Mann-Whitney U-test $(p<$ 0.001). DNAMAN software was used to examine DNA sequences. (version 6.0; LynnonBiosoft, U.S.A.).

\section{Results}




\section{Baseline sensitivity of $L$. Theobromae to difenoconazole.}

The $\mathrm{EC}_{50}$ values of difenoconazole to inhibit mycelial growth of $138 \mathrm{~L}$. theobromae field isolates ranged from 0.01 to $13.72 \mu \mathrm{g} / \mathrm{ml}$. After the outliers were excluded by boxplot, it showed a continuous unimodal log-normal distribution of sensitivity of 121 isolates to difenoconazole $(W=0.981, P=0.087)$ (Fig. 1$)$. The mean $\mathrm{EC}_{50}$ value of 121 isolates was $1.12 \pm 1.09 \mu \mathrm{g} / \mathrm{ml}$, adopted as the resistance threshold concentration. Twenty-one of the 138 isolates were categorised as resistant to difenoconazole based on baseline sensitivity. The $\mathrm{EC}_{50}$ values of resistant isolates ranging from 5.60 to $13.72 \mathrm{~g} / \mathrm{ml}$, and the resistance factors ranged from 5 to 12.25. The resistance frequencies of $L$. theobromae isolates against difenoconazole was $15.22 \%$. The resistant isolates could grow in the medium containing $150 \mu \mathrm{g} / \mathrm{ml}$ of difenoconazole (Fig. 2).

\section{Cross-resistance.}

The EC50 of 20 isolates to carbendazim, pyraclostrobin, fludioxonil, bromothalonil, iprodione and tebuconazole were ranged $0.0001-8537.14 \mu \mathrm{g} / \mathrm{ml}, 0.0008-1913.83 \mu \mathrm{g} / \mathrm{ml}, 0.04-0.26 \mu \mathrm{g} / \mathrm{ml}, 2.081-$ $16.58 \mu \mathrm{g} / \mathrm{ml}, 0.23-0.54 \mu \mathrm{g} / \mathrm{ml}$ and $0.07-1.87 \mu \mathrm{g} / \mathrm{ml}$, respectively (Table 2). The results showed that multifungicide-resistant isolates of $L$. theobromae were found. Among 20 isolates used in this study, resistant isolates were resistant to either two (9 isolates), three (1 isolates), or four fungicides (2 isolate) .

There was no correlation between sensitivity to difenoconazole and that to carbendazim $(\rho=0.493, P=$ 0.253; Fig. 3A), pyraclostrobin ( $\rho=-0.047, P=0.519$; Fig. 3B), fludioxonil ( $\rho=-0.078, P=0$. 878; Fig. 3C), bromothalonil ( $\rho=-0.173, P=0.509$; Fig. 3D), iprodione $(\rho=0.024, P=0.929 ;$ Fig. 3E). Only a positive correlation was observed between sensitivity to difenoconazole and that to tebuconazole $(\rho=0.836, P=$ 0.001; Fig. 3F).

\section{Cloning and characterization of LtCYP51.}

The nucleotide sequences of the $1797 \mathrm{bp}$ fragment of the LtCYP51 gene from the isolates were found to be $99 \%$ identical to that of $L$. theobromae (Genbank accession number MK107983.1). The LtCYP51 gene fragment encodes 523 amino acids and has two introns of $49 \mathrm{bp}$ each at nucleotide positions 247 and 494, respectively. The BLAST search amino acid sequence of the LtCYP51 protein also showed $100 \%$, 94.5\% and $93.1 \%$ identity with that of the CYP51 protein in L. theobromae from cacao (XP_035367211.1), Diplodiaseriata from grape (OMP84122.1) and Botryosphaeria dothidea from apple (KAF4310083.1), respectively.

\section{Comparison of LtCYP51 gene and its upstream region in sensitive and resistant isolates.}


The 30 isolates were analyzed for the sequence of $\angle t C Y P 51$ genes and their upstream regions. Based on the alignment, two mutant phenotypes were found. An E209k mutation (glutamic acid was replaced with lysine) on the LtCYP51 protein was found in the resistant isolate YC80 and the sensitive isolate YC70. Meanwhile, a G207A mutation (the amino acid glycine was replaced by alanine) was only found in the isolate YC70 (Fig. 4). In the other resistant isolates, no mutation was found.

Fragments about 500 bp upstream portion of the LtCYP51 gene were obtained using the primer pair Per$1 F /$ Per-1R. The upstream regions were identical in all tested isolates. In any of the isolates tested, no mutations or insertions were identified in the promoter of the LtCYP51 gene.

\section{Relative expression of LtCYP51 in sensitive and resistant isolates.}

To explore the mechanism of resistance, the expression levels of the LtCYP51 gene in resistant and sensitive isolates were tested. Our results showed that difenoconazole significantly induced LtCYP51 expression in the resistant isolates $(p<0.01)$ (Fig. 5A). The mean constitutive relative expressions of LtCYP51 without fungicide in the two sensitive and six resistant isolates were 1.05 and 1.7 times, respectively. Difenoconazole increased the relative expression of LtCYP51 by 1.87 to 2.06 times in sensitive isolates with an average of 1.97 , but 6.71 to 12.41 times in resistant isolates with an average of 10.05 times. In the resistant isolates, the mean relative expression of LtCYP51 induced by difenoconazole was 5 -fold higher than that of sensitive isolates, and there was a significant difference $(p<0.001)$ (Fig. $5 B)$.

\section{Discussion}

Mango diseases are widely controlled using site-specific systemic fungicides in almost all mangogrowing regions in the world. The detection of fungicide resistance is a crucial step in monitoring and regulating the spread of resistance in the field ${ }^{20}$. Among systemic fungicides, MBC fungicides are inhibitors of tubulin biosynthesis and impede cell division and inhibited mycelial growth ${ }^{21}$. Unfortunately, MBCs resistant populations of $L$. theobromae have been confirmed from papaya, citrus and mango ${ }^{11,22-25}$. Further, DMls fungicides were more favoured by orchardist due to their specific mode of action and broad anti-fungi spectrum. DMI fungicides are classified as a medium risk for resistance development by the Fungicide Resistance Action Committee ${ }^{26}$. However, DMls resistance has been found in a variety of phytopathogenic fungi ${ }^{17,16,20}$. The resistance mechanisms of DMls have been reported to be diverse, with the following being the primary mechanisms: (I) point mutations in the target gene $14 \alpha$ demethylase (CYP51) 27-29; (II) CYP51 gene overexpression 30-34, 16; (III) Overexpression of efflux proteins $^{35,36}$. In this study, we established the baseline sensitivity of $L$. theobromae to difenoconazole using 121 isolates from five major mango producing regions in Hainan, China. The results showed that the $\mathrm{EC}_{50}$ values ranged from 0.01 to $13.72 \mu \mathrm{g} / \mathrm{ml}$, with a mean $\mathrm{EC}_{50}$ value of $1.1 \mu \mathrm{g} / \mathrm{ml}$, suggesting that it 
could be used as a criterion to judge difenoconazole resistance in further studies. Twenty-one difenoconazole-resistant isolates were found in this study; their $\mathrm{EC}_{50}$ values ranged from 5.61 to 13.72 $\mu \mathrm{g} / \mathrm{ml}$. Furthermore, the $\mathrm{EC}_{50}$ values of 79 isolates were above $1 \mu \mathrm{g} / \mathrm{ml}$, which accounted for more than half of the isolates. It means that there were a large number of isolates with reduced sensitivity to difenoconazole. Meanwhile, resistant isolates showed positive cross-resistance to difenoconazole and tebuconazole. In addition, no cross-resistance was discovered in this investigation between DMIs and non-DMls fungicides. This matches reports of Botrytis cinerea and Colletotrichum gloeosporioides resistance to DMIs ${ }^{16,37}$. The commonly used site-specific fungicides (such as carbendazim and azoxystrobin) gave bad control effect against $L$. theobromae due to the development of resistant isolates. With frequent applications of DMIs fungicides in fields, the development of DMIs fungicide resistance is a major challenge for diseases effective control of the fruit planting in China. It is suggested that the appropriate management strategies of fungicide resistance should be used, such as reducing the usage of DMls fungicides combining and alternative fungicides with distinct modes of action that have not been found to cross-resistance for better management of SER. For the control of $L$. theobromae, mixtures of difenoconazole and other chemical fungicides, as well as the botanical fungicide Thymol, have been reported to be particularly effective ${ }^{38}$. These managements can reduce pathogen population selection pressure, slowing the development of DMI resistance.

The target site of action of DMIs is the enzyme CYP51. The point mutations of CYP51 gene changes the conformation of the target protein, resulting in the decrease of the binding ability of fungicides to the target protein. Moreover, many point mutations in CYP51 gene of various plant diseases have also been found ${ }^{39-41}$. Additionally, mutations and overexpression of CYP51 gene have been observed simultaneously in some DMls-resistant isolates of plant pathogens ${ }^{17,42,20}$. An increase in DMI fungicide application dosages would not improve their efficacy in the case of mutation. In this study, two point mutations E209K and G207A, were found in LtCYP51 in a sensitive isolates YC70, and the point mutation E209K were found in a resistant isolates YC80 with the same as one found in YC70. We concluded that point mutation of $L$. theobromae maybe not the cause of low-level resistance to difenoconazole. Although most research studies claim that target site change caused resistance in the majority of DMls resistance isolates, additional resistance mechanisms cannot be ruled out. Our study showed that overexpression of $L t C Y P 51$ of resistant isolates was observed in response to difenoconazole. This is consistent with what has been found in Mycosphaerella graminicola of wheat, Blumeriella jaapii of cherry and Neophysopella meliosmae-myrianthae of grapevine ${ }^{30,43,44}$. Overexpression of CYP51 caused by promoter insertions or retrotransposons has only been described in a few phytopathogenic fungi so far. For example, a 199-bp sequence duplication was discovered at the promoter of CYP51 of Penicillium digitatum ${ }^{45}$. However, underlying mechanisms of CYP51 overexpression are not known for in the field DMl-resistant subpopulations of Puccinia triticina ${ }^{39}$, Sclerotinia homoeocarpa ${ }^{46}$, Pyrenophora teres ${ }^{17}$, Colletotrichum gloeosporioides ${ }^{16}$, Botrytis cinerea $^{37}$. We tried to clone and sequence analysis the promoter of $L t C Y P 51$ in this study. However, the promoter of $L t C Y P 51$ from difenoconazole-resistant $L$. 
theobromae isolates did not show any mutations or insertions. The molecular mechanism of LtCYP51 overexpression needs further investigation.

In brief, DMIs have diminished sensitivity in field populations due to their long-term and intensive use. In the mango fields of China, Hainan Province, L. theobromae has acquired a low to moderate difenoconazole resistance. Although there existed obvious positive cross resistance between difenoconazole and tebuconazole, no cross-resistance was found between difenoconazole and non-DMI fungicides. Control measures such as rotation and mixture treatments with different modes of action fungicides can reduce the emergence of resistant isolates in the field. Compared with the difenoconazolesensitive isolates, there were no mutations in the CYP51 gene of resistant isolates at position 132, 137 or any others (markers for resistance in DMls fungicides). However, induced expression of CYP51 of resistance isolates is involved in the resistance to difenoconazole. In the future, more research work should focus on exploring the mechanisms that induce CYP51 expression in L. theobromae. Improved knowledge of fungicide resistance evolution and of the molecular mechanisms by which this occurs will be necessary to implement suitable control strategies that will reduce the likelihood of fungicide resistance outbreaks. Our findings are critical for controlling the high-risk pathogen $L$. theobromae and would help to slow down or even prevent the emergence of DMls fungicide resistance.

\section{Declarations}

\section{Author contributions}

C.W. participated in research design, laboratory experiments, statistical analysis and writing of the paper. L.X. participated in research design, data interpretation, and writing of the paper. X.L. participated in laboratory experiments and revision the paper. J.W. and X.X. participated in laboratory experiments. Y.Z. participated in research design, data interpretation, and writing of the paper. Y.Y. participated in research design, data interpretation and writing of the paper, supervised the project. All authors reviewed the manuscript.

\section{Funding}

The study was supported by the National Natural Science Foundation of China (Grant No.: 31560521).

\section{Competing interests}

The authors declare no competing interests.

\section{Statement}


the use of plants parts in the present study complies with Regulations of the people's Republic of China on the protection of wild plants

\section{References}

1. Xu, B. \& Wu, S. j. Preservation of mango fruit quality using fucoidan coatings. Lwt-Food. Sci. Technol, 143, 111150 https://doi.org/10.1016/j.Iwt.2021.111150 (2021).

2. China Industrial Information Network. Analysis on mango varieties, planting area, yield pattern in Hainan province in 2019 and development counter measures in 2020. https://www.chyxx.com/industry/202012/913659.html (2020).

3. Wang, M. et al. Fungicide-resistance and genetic diversity of Botryodiplodia theobromae from mango causing stem-end rots in fruits in Hainan. Chin. J. Tropl. Crop, 37, 1363-1369 (2016). http://en.cnki.com.cn/Article_en/CJFDTOTAL-RDZX201607019.htm

4. Baltazari, A. et al. Evaluation of post-harvest losses and shelf life of fresh mango (Mangifera indica L.) in eastern zone of Tanzania. Int. J. Fruit. Sci, 20, 855-870 https://doi.org/10.1080/15538362.2019.1697411 (2019).

5. Feygenberg, O. et al. Improved management of mango fruit though orchard and packinghouse treatments to reduce lenticel discoloration and prevent decay. Postharvest. Biol. Tec, 91, 128-133 https://doi.org/10.1016/j.postharvbio.2014.01.001 (2014).

6. Galsurker, O. et al. Harvesting mango fruit with a short stem-end altered endophytic microbiome and reduce stem-end rot. Microorganisms, 8, 4 https://doi.org/10.3390/microorganisms8040558 (2020).

7. Rodríguez-Gálvez, E., Hilário, S., Lopes, A. \& Alves, A. Diversity and pathogenicity of Lasiodiplodia and Neopestalotiopsis species associated with stem blight and dieback of blueberry plants in Peru. Eur. J. Plant. Pathol, 157, 89-102 https://doi.org/10.1007/s10658-020-01983-1 (2020).

8. Santos, P. H. D. et al. Is Lasiodiplodia theobromae the only species that causes leaf blight disease in Brazilian coconut palms? Trop. Plant. Pathol, 45, 434-442 https://doi.org/10.1007/s40858-02000344-x (2020).

9. Chen, F. P. et al. Reduced sensitivity of azoxystrobin and thiophanate-methyl resistance in Lasiodiplodia theobromae from papaya. Pestic. Biochemistry. Phys, 162, 60-68 https://doi.org/10.1016/j.pestbp.2019.08.008 (2020).

10. Zhang, S. et al. Lasiodiplodia theobromae (Pat.) Griff. \& Maubl. reduced energy status and ATPase activity and its relation to disease development and pericarp browning of harvested longan fruit. Food. Chem, 275, 239-245 https://doi.org/10.1016/j.foodchem.2018.09.105 (2018).

11. Pereira, A. V., Martins, R. B., Michereff, S. J., Silva, M. B. \& Câmara, M. P. S. Sensitivity of Lasiodiplodia theobromae from Brazilian papaya orchards to MBC and DMI fungicides. Eur. J. Plant. Pathol, 132, 489-498 https://doi.org/10.1007/s10658-011-9891-2 (2012). 
12. Shah, M. U. D. \& Verma, K. S. In vitro evaluation of fungitoxicants against Botryodiplodia theobromae isolates causing die-back of pear and mango. SKUAST. J. Research, 19, 173-180 (2017).

13. Yang, Y. et al. Multifungicide resistance profiles and biocontrol in Lasiodiplodia theobromae from mango fields. Crop. Prot, 145, 105611 https://doi.org/10.1016/j.cropro.2021.105611 (2021).

14. Price, P. P. et al. Fungicide resistance in Cercospora kikuchii, a soybean pathogen. Plant. Dis, 99 , 1596-1603 https://doi.org/10.1094/PDIS-07-14-0782-RE (2015).

15. FAO. Recommended methods for the detection and measurement of resistance of agricultural pests to pesticides. FAO. Plant. Prot. Bull, 2, 39-42 (1982). https://agris.fao.org/agrissearch/search.do? request_locale=ar\&recordID $=X F 19800529554$

16. Wei, L. L. et al. Mutations and overexpression of CYP51 associated with dmi-resistance in colletotrichum gloeosporioides from chili. Plant. Dis, 104, 668-676 https://doi.org/10.1094/PDIS-0819-1628-RE (2020).

17. Mair, W. J. et al. Demethylase inhibitor fungicide resistance in Pyrenophora teres f. sp. teres associated with target site modification and inducible overexpression of CYP51. Front. Microbiol, 7, 1279 https://doi.org/10.3389/fmicb.2016.01279 (2016).

18. Li, Y. et al. Characterization of difenoconazole resistance in Lasiodiplodia theobromae from papaya in Brazil. Pest. Manag. Sci, 76 (4), https://doi.org/10.1002/ps.5645 (2019).

19. Sedgwick, P. Spearman's rank correlation coefficient. Br. Med. J, 349, 7327 https://doi.org/10.1136/bmj.g7327 (2014).

20. Zhang, C. et al. Two point mutations on cyp51 combined with induced expression of the target gene appeared to mediate pyrisoxazole resistance in Botrytis cinerea. Front. Microbiol, 11, 1396 https://doi.org/10.3389/fmicb.2020.01396 (2020).

21. David, V. C., Diego, R., Antonio, V. \& Alejandro, P. G. Analysis of $\beta$-tubulin-carbendazim interaction reveals that binding site for $\mathrm{MBC}$ fungicides does not include residues involved in fungicide resistance. Sci. Rep, 8, 7161 https://doi.org/10.1038/s41598-018-25336-5 (2018).

22. Rehman, A. et al. Emerging resistance against different fungicides in Lasiodiplodia theobromae as the cause of mango dieback in Pakistan. Arch. Biol. Sci, 67, 241-249 https://doi.org/10.2298/ABS140904030R (2015).

23. Yang, Y., Zeng, G. D., Zhang, Y., Xue, R. \& Hu, Y. J. Molecular and Biochemical Characterization of Carbendazim-Resistant Botryodiplodia theobromae Field Isolates. Plant. Dis, 103, 2076-2082 https://doi.org/10.1094/PDIS-01-19-0148-RE (2019).

24. Zhang, J. X. \& Timmer, L. W. Preharvest application of fungicides for postharvest disease control on early season tangerine hybrids in Florida. Crop. Prot, 26, 886-893 https://doi.org/10.1016/j.cropro.2006.08.007 (2006).

25. Zhao, L., Yang, Y., Wang, M., He, R. \& Chen, M. C. Sensitivities of carbendazim-resistance and fitness of Botryodiplodia theobromae isolates from mango in Hainan. Chin. J. Pestic. Sci, 19, 1-9 (2017). http://en.cnki.com.cn/Article_en/CJFDTOTAL-NYXB201703005.htm 
26. FRAC Code List. Fungicide sorted by mode of action. http://www.frac.info/docs/defaultsource/publications/frac-code-list/frac_code_list_2018-final.pdf?sfvrsn=6144b9a_2 (2018).

27. Chowdhary, A. et al. Isolation of multiple-triazole-resistant Aspergillus fumigatus strains carrying the TR/L98H mutations in the cyp51A gene in India. J. Antimicrob. Chemoth, 67, 362-366 https://doi.org/10.1093/jac/dkr443 (2012).

28. Schmitz, H. K., Medeiros, C. A., Craig, I. R. \& Stammler, G. Sensitivity of Phakopsora pachyrhizi towards quinone-outside-inhibitors and demethylation-inhibitors and corresponding resistance mechanisms. Pest. Manag. Sci, 70, 378-388 https://doi.org/10.1002/ps.3562 (2014).

29. Wang, F. et al. The Y137H mutation of VvCYP51 gene confers the reduced sensitivity to tebuconazole in Villosiclava virens. Sci. Rep, 5, 17575 https://doi.org/10.1038/srep17575 (2015).

30. Cools, H. J., Bayon, C., Atkins, S., Lucas, J. A. \& Fraaije, B. A. Overexpression of the sterol 14ademethylase gene (MgCYP51) in Mycosphaerella graminicola isolates confers a novel azole fungicide sensitivity phenotype. Pest. Manag. Sci, 68, 1034-1040 https://doi.org/10.1002/ps.3263 (2012).

31. Carter, H. E. et al. Alterations in the predicted regulatory and coding regions of the sterol 14ademethylase gene (CYP51) confer decreased azole sensitivity in the oilseed rape pathogen Pyrenopeziza brassicae. Mol. Plant. Pathol, 15, 513-522 https://doi.org/10.1111/mpp.12106 (2014).

32. Hulvey, J., Popko, J. T., Sang, H., Berg, A. \& Jung, G. Overexpression of Sh CYP51B and Shatr D in Sclerotinia homoeocarpa isolates exhibiting practical field resistance to a demethylation inhibitor fungicide. Appl. Environ. Microb, 78, 6674-6682 https://doi.org/10.1128/AEM.00417-12 (2012).

33. Nikou, D. et al. Molecular characterization and detection of overexpressed C-14 alpha-demethylasebased DMI resistance in Cercospora beticola field isolates. Pestic. Biochem. Phys, 95, 18-27 https://doi.org/10.1016/j.pestbp.2009.04.014 (2009).

34. Rodriguez-Tudela, J. L. et al. Epidemiological cutoffs and cross-resistance to azole drugs in Aspergillus fumigatus. Antimicrob. Agents. Ch, 52, 2468-2472 https://doi.org/10.1128/AAC.0015608 (2008).

35. Leroux, P. \& Walker, A. S. Multiple mechanisms account for resistance to sterol 14a-demethylation inhibitors in field isolates of Mycosphaerella graminicola. Pest. Manag. Sci, 67, 44-59 https://doi.org/10.1002/ps.2028 (2011).

36. Omrane, S. et al. Fungicide efflux and the Mg MFS1 transporter contribute to the multidrug resistance phenotype in Zymoseptoria tritici field isolates. Environ. Microbiol, 17, 2805-2823 https://doi.org/10.1111/1462-2920.12781 (2015).

37. Zhang, C. et al. Difenoconazole resistance shift in Botrytis cinerea from tomato in china associated with inducible expression of CYP51. Plant. Dis, 105, 400-407 https://doi.org/10.1094/PDIS-03-200508-RE (2020).

38. Ye, H. C., Zhou, Y., Zhang, J., Yan, C. \& Feng, G. Synergistic toxicity of thymol and difenoconazole on mango pathogenic fungi Botryodiplodia theobroma. Chin. J. Trop. Agric, 35, 89-93 (2015). 
http://en.cnki.com.cn/Article_en/CJFDTOTAL-RDNK201512017.htm

39. Stammler, G., Cordero, J., Koch, A., Semar, M. \& Schlehuber, S. Role of the Y134F mutation in CYP51 and overexpression of CYP51 in the sensitivity response of Puccinia triticina to epoxiconazole. Crop. Prot, 28, 891-897 https://doi.org/10.1016/j.cropro.2009.05.007 (2009).

40. Fan, J. et al. The Y123H substitution perturbs FvCYP51B function and confers prochloraz resistance in laboratory mutants of Fusarium verticillioides. Plant. Pathol, 63, 952-960 https://doi.org/10.1111/ppa.12168 (2014).

41. Chen, F. P. et al. Heterologous expression of the Monilinia fructicola CYP51 (MfCYP51) gene in Pichia pastoris confirms the mode of action of the novel fungicide, SYP-Z048. Front. Microbiol, 6, 457 https://doi.org/10.3389/fmicb.2015.00457 (2015).

42. Rallos, L. E. E. \& Baudoin, A. B. Co-occurrence of two allelic variants of CYP51 in Erysiphe necator and their correlation with over-expression for DMI resistance. PloS. One, 11, 0148025 https://doi.org/10.1371/journal.pone.0148025 (2016).

43. Ma, Z. H., Proffer, T. J., Jacobs, J. L. \& Sundin, G. W. Overexpression of the 14 a-demethylase target gene (CYP51) mediates fungicide resistance in Blumeriella jaapii. Appl. Environ. Microb, 72, 25812585 https://doi.org/10.1128/AEM.72.4.2581-2585.2006 (2006).

44. Santos, R. F., Amorim, L., Wood, A. K. M., Bibiano, L. B. \& Fraaije, B. Lack of an intron in cytochrome b and overexpression of sterol 14a-demethylase indicate a potential risk for Qol and DMI resistance development in Neophysopella spp. on grapes. Phytopathology, https://doi.org/10.1094/PHYTO-1120-0514-R (2021).

45. Sun, X. P., Wang, J. Y., Feng, D., Ma, Z. H. \& Li, H. Y. PdCYP51B, a new putative sterol 14a-demethylase gene of Penicillium digitatum involved in resistance to imazalil and other fungicides inhibiting ergosterol synthesis. Appl. Microbiol. Biot, 91, 1107-1119 https://doi.org/10.1007/s00253-0113355-7 (2011).

46. Ma, B. \& Tredway, L. P. Induced overexpression of cytochrome P450 sterol 14alpha-demethylase gene (CYP51) correlates with sensitivity to demethylation inhibitors (DMIs) in Sclerotinia homoeocarpa.Pest. Manag. Sci.69,1369-1378. https://doi.org/10.1002/ps.3513(2013

\section{Figures}




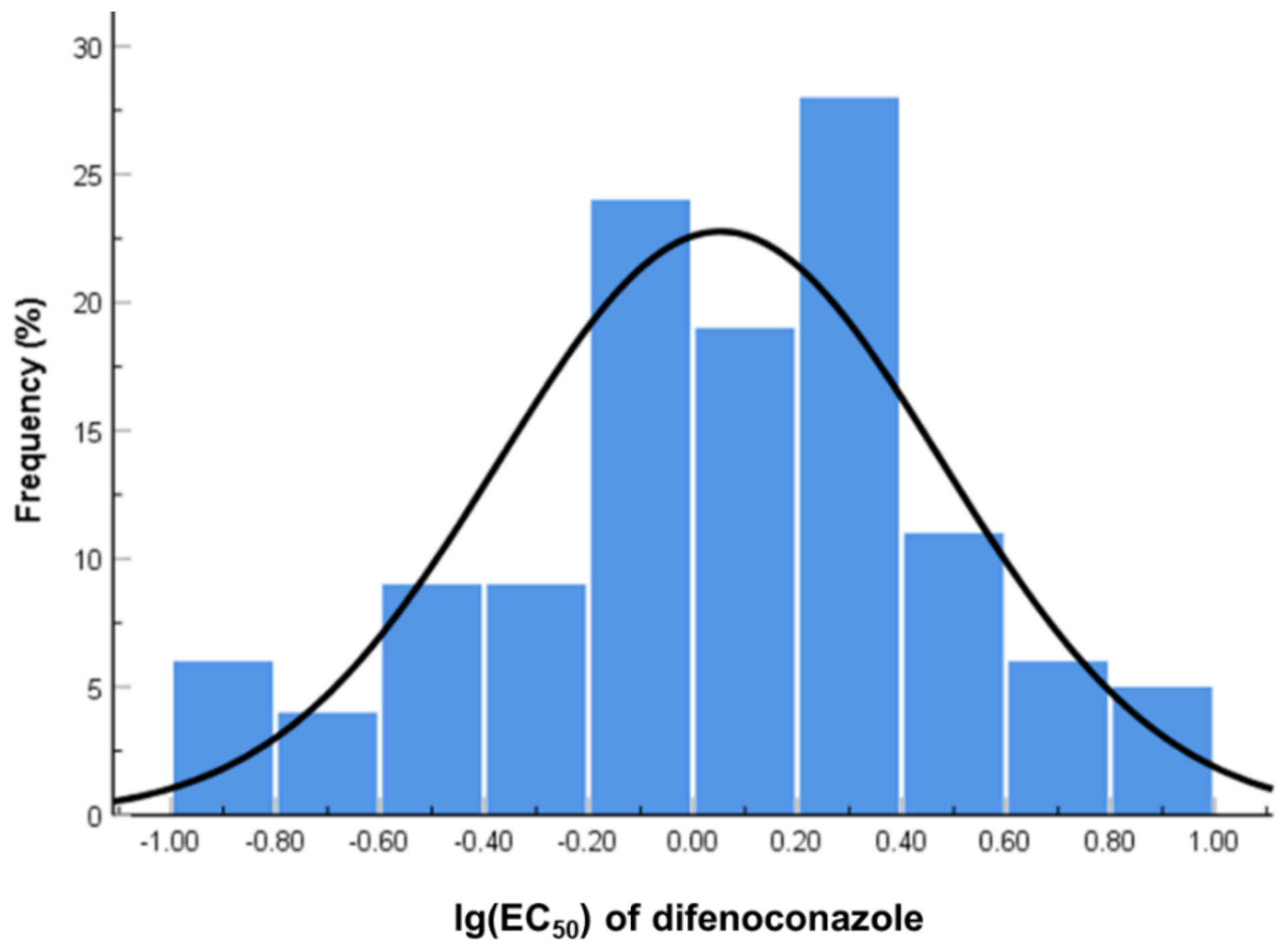

Figure 1

Frequency distribution of $\lg (\mathrm{EC} 50)$ values of difenoconazole against 121 Lasiodiplodia theobromae isolates when the outliers were excluded.

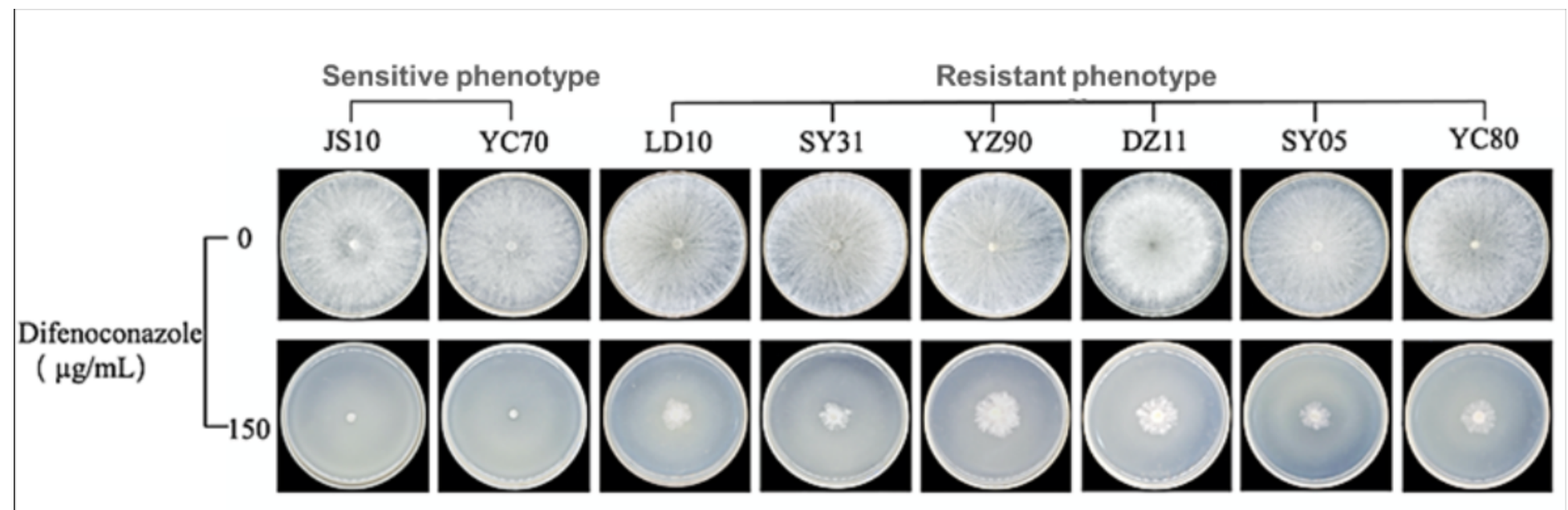

Figure 2 
Mycelia colony growth of the eight Lasiodiplodia theobromae isolates on PDA plates with and without difenoconazole.
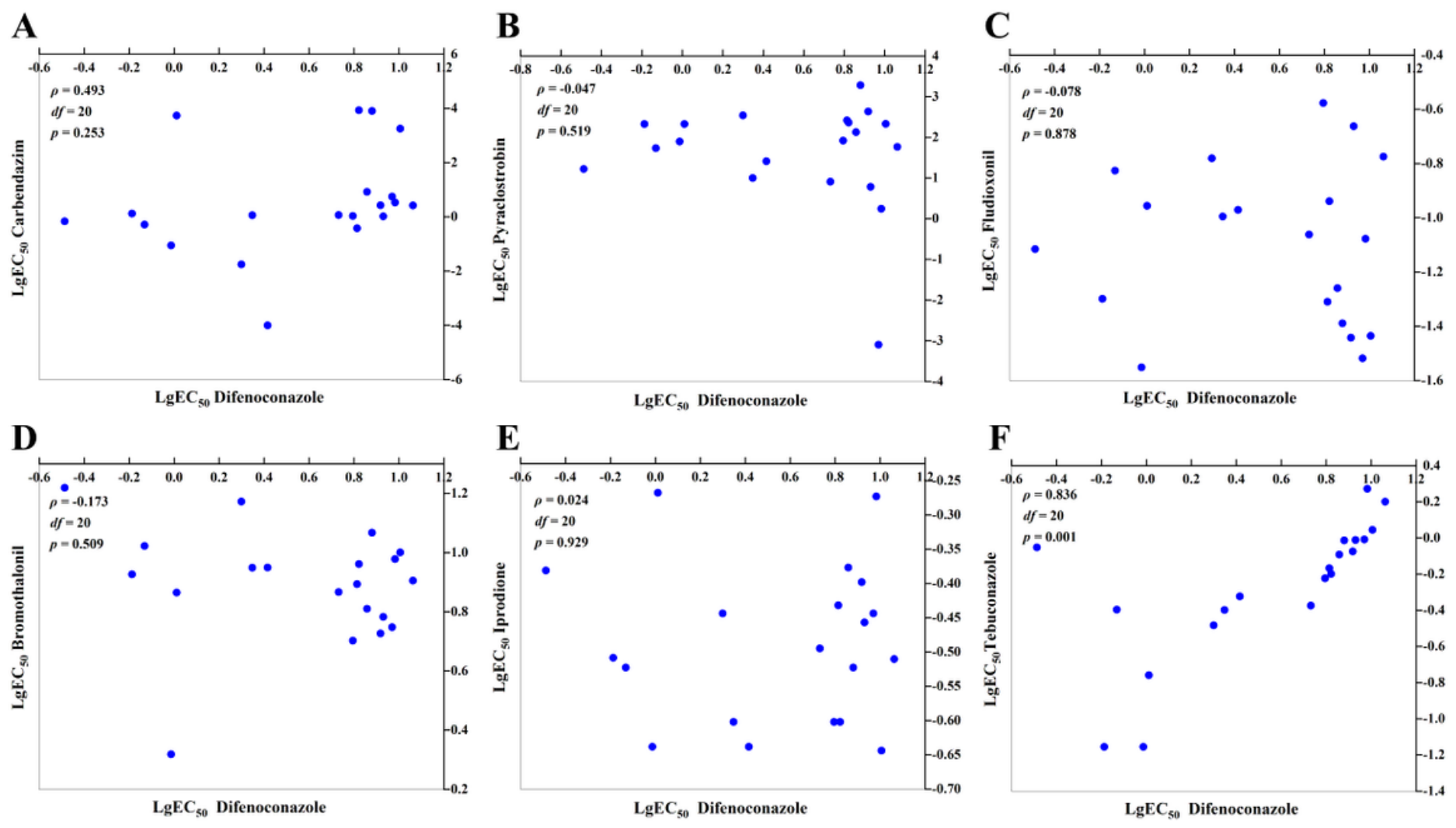

\section{Figure 3}

Cross-resistance between difenoconazole and carbendazim (A), pyraclostrobin (B), fludioxonil (C), bromothalonil (D), iprodione $(E)$, tebuconazole $(F)$ by rank correlation analysis. Data shown in logarithmic values of EC50 among Lasiodiplodia theobromae for fungicide combinations. 
61

271

1441

481

1531 511

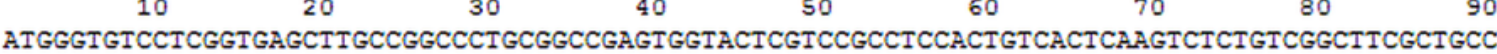

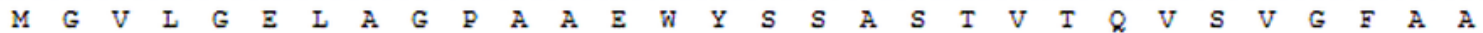
$\begin{array}{llllllll}100 & 110 & 120 & 130 & 140 & 150 & 160 & 170\end{array}$ GICITCITCGCGTCCATCTICCICAACGICCTGAGGCAGCTTCIGCTCAAGGACCCCAAGAAGCCICCCGICGICITCCACITCGIGCCG $\begin{array}{llllllllllllllllllllllllllllllll}V & F & F & A & S & I & F & L & N & V & L & R & Q & L & L & L & K & D & P & K & K & P & P & V & V & F & H & F & V & P\end{array}$ GIACGIGITCITITCGGCTGCGAITGGCTCGCGIGCCITGGCTGACCGCGAIGACGCAICAARG

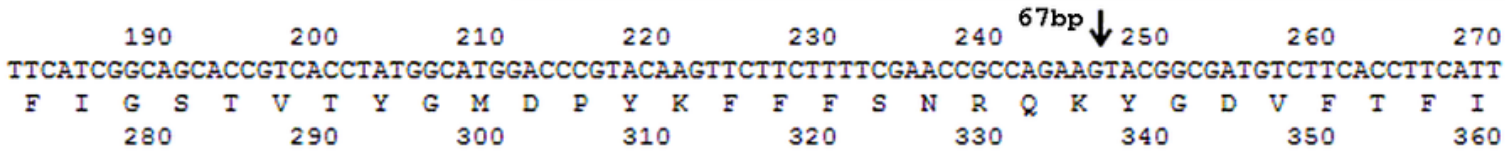
CTGCTCGGCAAGCCGACCACCGTCTGCCTGGGCACTAAGGGCAACGACITCATCCTGAACGGCAAGCTCAAGGACGTCAATGCCGAGGAG

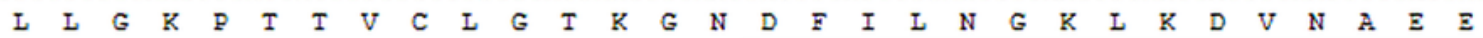
GTACCGCCGCGCTTCACCOGAGCOCGCGCAGGATGCTGATTCGTGCCGCAG

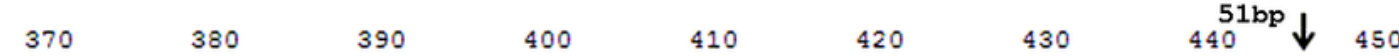
ATCTACAGCCCTCTCACCACTCCGGTTITCGGCAAGGATGTCGTCTACGACTGCCCCA.ACTCCAAAGCTCATGGAGCAGAAGAAGTTCGTC

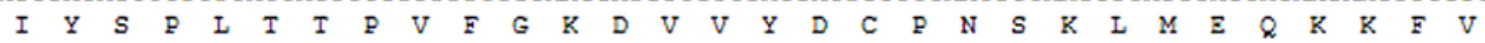

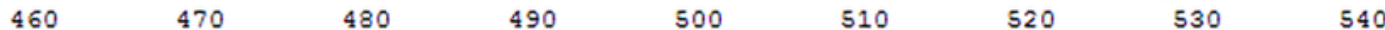
AAGTTCGGCCTGACCAGCGACGCTCTCCGGTCCTACGICGACCTGATCACCTCCGAGGTCCAGGACTACGTCAAGCGCACCCCCAACTTC $\begin{array}{lllllllllllllllllllllllllllllllll}K & F & G & L & I & S & D & A & L & R & S & Y & V & D & L & I & T & S & E & V & Q & D & Y & V & K & R & T & P & N & F\end{array}$ $\begin{array}{llllllll}550 & 560 & 570 & 580 & 590 & 600 & 610 & 620\end{array}$ AAGGGCGAAATCGGCACCATTGATGTCCCGCAGACCATGGCCGAAATCACCATCTTTACCGCCTCGCGCTCGCTGCAGGCCEGGAAGIG

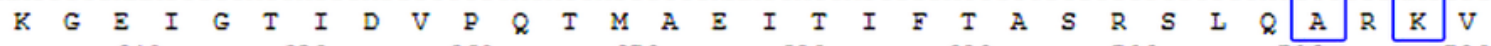
$\begin{array}{lllllllllllll}640 & 650 & 660 & 670 & 680 & 690 & 700 & 710 & 720\end{array}$ CGIGAGAAATTCGATGCCTCGITCGCCGATCTGTACCACGACCIGGACATGGGCTTCACICCGATCAACTICATGCTTCCCTGGGCCCCT

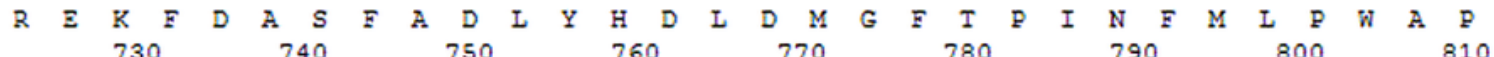
CTGCCCCAGAACAGGCGCCGCGACTTCGCGCACAACAAGATGGTTGAGGTCTACACGGACATCATCAAGGCCAGA.AGGGGGGTAAGGTG

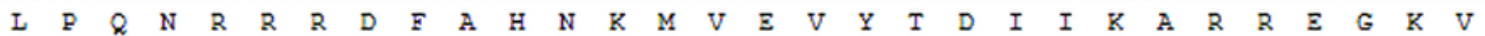
$\begin{array}{lllllllll}820 & 830 & 840 & 850 & 860 & 870 & 880 & 890 & 900\end{array}$ CAGA.AGGAGGAGGAAGACATGATCTGGAACCTGATGGGCTCGACGTACAAGAACGGCACTCCTCTGCCCGACCGGGAGATTGCTTGCATG

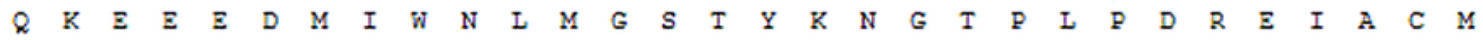

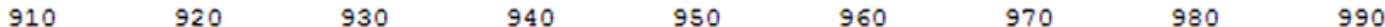
ATGATTGCGCTTCTCATGGCCGGCCAGCACTCTTCGTCGTCTACCATTTCCTGGATTGTGCTTCGTCTCGCCTCGCGGCCGGACATCACC

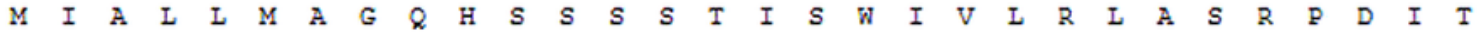

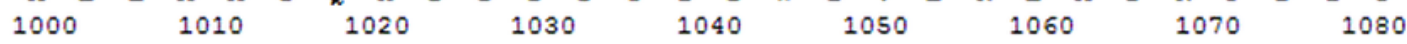
GAGGAGCTGCTCGAAGAGCAGAGACAGGTGCTGGGATCCGACCTTCCTCCGCTCAAGCACGAGGATCTTGCGAAACTGCCTCTCCACCAG $E \begin{array}{llllllllllllllllllllllllllllll} & \Xi & L & L & \Xi & \Xi & Q & R & Q & V & L & G & S & D & L & P & P & L & K & H & \Xi & D & L & A & K & L & P & L & H & Q\end{array}$

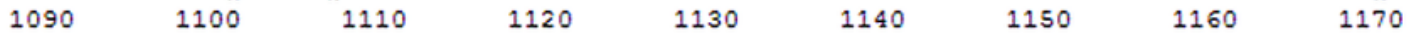
CAGGTGGTCA.AGGAGACGCTCCGCATCCACGCCCCGATCCACAGCATCATGCGCA.AGGTCAAGA_ACGACATGTIGATCGAGTCCA.ACCGC

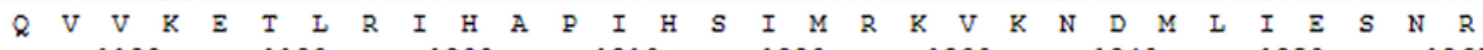

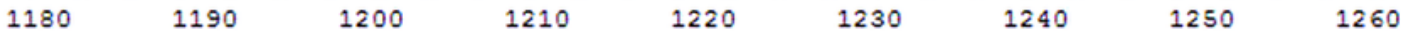
GGCA.AGACGTACACGATCCCCAGCGGCCACGTCCTCCTCGCCTCTCCTGGTGTTTCGGCCACGTCGGACGAGCACTTCCCCAACCCICAG

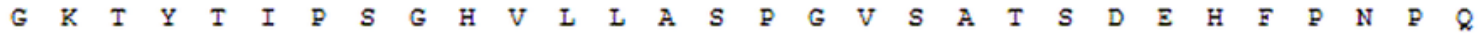

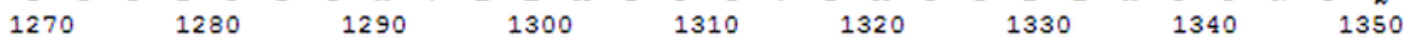
CAITGGGACCCGCACCGCTGGGACGGCA.AGCCGACGAGCAACGATTCGGCCGATGACGAACAGATCGACTACGGTTTCGGCATGGTGTCC $\begin{array}{llllllllllllllllllllllllllllllll}H & W & D & P & H & R & W & D & G & K & P & T & S & N & D & S & A & D & D & \Xi & Q & I & D & Y & G & F & G & M & V & S\end{array}$

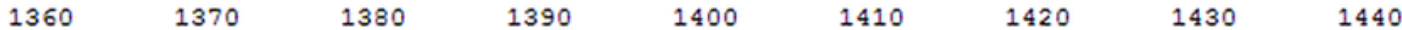
AAGGGCACCAACAGCCCCTACCTGCCCTTCGGCGCCGGCCGTCACAGGTGCATTGGCGAGCAATTCGCGTACGTGCAGCTGCAGACGATC $\begin{array}{lllllllllllllllllllllllllllllllll}K & G & I & N & S & P & Y & L & P & F & G & A & G & R & H & R & C & I & G & E & Q & F & A & Y & V & Q & I & Q & I & I\end{array}$ GTAGGTTCACCCTTCCCAGCAGATTCGACCCATTIGCTAACGCGCTCTAG

$$
1450 \quad 1460 \quad 1470 \quad 1480 \quad 1490 \quad 1500 \quad 1510^{50 b p} \downarrow \quad 1520 \quad 1530
$$
CTCGGCAACCTGGTCCGCGAGTICAAGTTCAGGAACATTGACAACTCGAACAACGIGGTCGGCACCGACTITTCGTCCATGICTCGCAGC $\begin{array}{lllllllllllllllllllllllllllllllll}L & G & N & L & V & R & E & F & K & F & R & N & I & D & N & S & N & N & V & V & G & T & D & F & S & S & M & S & R & S\end{array}$ CGCTCAGTCCGTCGTGIGGIGGITIGGGAGAGGAGGGAGAA

$\begin{array}{llllllllllllllllll}R & S & V & R & R & V & V & V & W & E & R & R & E\end{array}$

\section{Figure 4}

Partial sequences and deduced amino acid sequences of the LtCYP51 gene from sensitive Lasiodiplodia theobromae isolates YC70 (Accession number: MZ365052). The intron sequence is depicted in a solid line box with an arrow showing the insertion site. Two amino acid substitutions were found at position 207 and 209 (in blue box). 
A

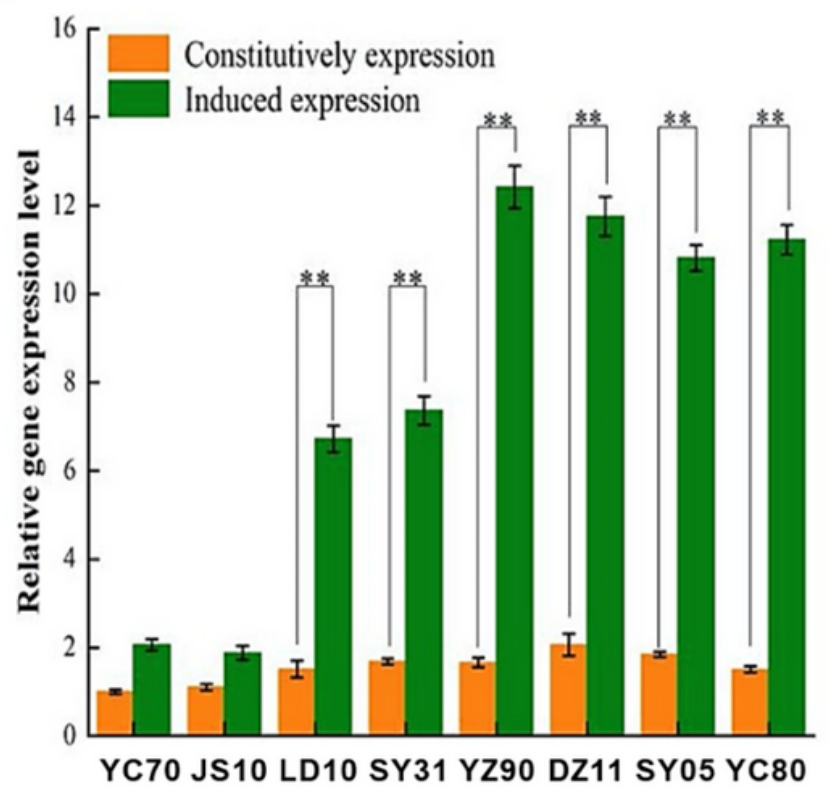

B

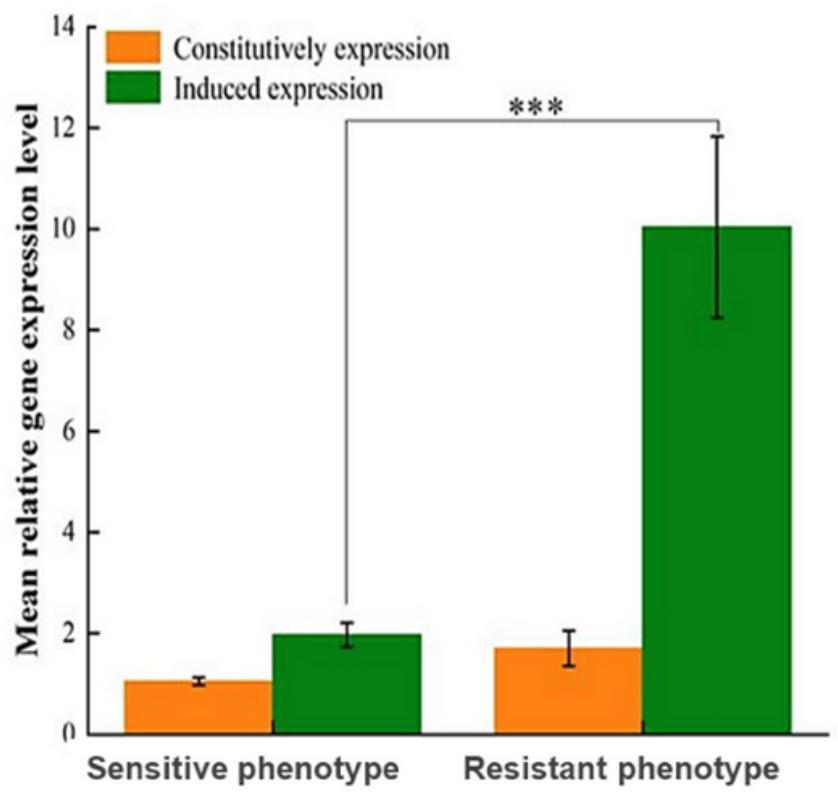

Figure 5

Expression of Ltcyp51 in the sensitive and resistant isolates of Lasiodiplodia theobromae before and after treated by difenoconazole. (A) Changes of relative expression levels of 8 isolates; (B) Changes of the mean relative expression levels of different phenotype. ** represent significant level $(p<0.01)$, *** represents significant level $(p<0.001)$. 